Received $\quad 03.04 .2019$

Reviewed $\quad 13.05 .2019$

Accepted 27.05.2019

A - study design

B - data collection

C - statistical analysis

D - data interpretation

E - manuscript preparation

F - literature search

\section{Identifying the pool-point bar location based on experimental investigation}

\author{
Jaafar S. MAATOOQ ${ }^{1) \text { ADE }}$, Luay HAMEED ${ }^{2) \text { BCF }}$
}

1) orcid.org/0000-0003-3085-0893; University of Technology, Faculty of Civil Engineering, PO Box 35010, Tel Mohammad, Baghdad, Iraq; e-mail: jaafarmaatooq@gmail.com

2) orcid.org/0000-0001-9974-2634; University of Kufa, Faculty of Engineering, Kufa, Najaf Governorate, Iraq; e-mail: luayk.alwaeli@uokufa.edu.iq

For citation: Maatooq J.S., Hameed L. 2019. Identifying the pool-point bar location based on experimental investigation. Journal of Water and Land Development. No. 43 (X-XII) p. 106-112. DOI: 10.2478/jwld-2019-0068.

\begin{abstract}
Morphological relationships of meander evolution in terms of hydraulic and geometric characteristics are essential for river management. In present study, an experimental based study of meander evolution was employed to develop a prediction formula for identifying the pool-point bar location by using the dimensional analysis technique and multiple nonlinear regressions. Through the experimental work on a race of the non-uniform river sand, a set of experimental runs have been carried out through combining different hydraulic and geometric parameters to produce different empirical conditions that have a direct impact on the pool-point bar location. Based on the experimental observations and measurements, the variation in pool-point bar locations could be interpreted to that the hydraulic and morphologic properties through the meander evolution were varied during the time causes the variations in the patterns of the pool-point bar formations accordingly. The developed formula was verified by using another set of the experimental data and tested with three statistical indicators. The predicted results indicated that the proposed formula had high reliability for practical estimation of the pool-point bar location. This reliability was tested by the statistical indicators, where the less values have been resulted for bias and mean absolute error $(M A E), 0.0004$ and 0.0110 respectively, whereas the higher values 0.935 and 0.930 are achieved for the Nash-Sutcliffe efficiency (NSE) and the determination coefficient $R^{2}$, respectively.
\end{abstract}

Key words: experimental investigation, meander evolution, morphologic properties, pool-point bar, river sand

\section{INTRODUCTION}

The evolution of alluvial bed and bank erosion through meanders development consists of morphologic aspects as a pool due to erosion and as a point bar when the depositions occur. Each morphologic aspect contains pool-point bar forms an erosion-deposition zone with pools placed at the apex of meander bends (outer bank) and point bar located at inner bank. The evolution of a pattern of point bar-pool is considered as an essential characteristic of alluvial meandering rivers [Keller 1972] (cited by YILMAZ [2011]). As can be shown from Figure 1 some of pool-point bar zones (erosion-deposition zones) are located approximately between the apex and crossing sections (Fig. 1a), and other zones are centered approximately around the apex
(Fig. 1b), which means that the formation of the pool-point bar has no specific location therefore its location depends on the hydraulic and geometric characteristics of the meander zone. Several researchers investigated the location of the pool-point bar. WHITING and DIETRICH [1993] showed that the location in flow plan of the erosion-deposition zones are depending on the plan form of the stream.

YALIN and DA SILVA [2001] concluded by using dimensional analysis that the location of the erosiondeposition units may be expected to vary with the plan form characteristics of the stream, width/depth ratio, and the dimensionless flow friction factor (which reflects the effect of the granular skin roughness). DA SILVA and ELTAHAWY [2008], examined the effect of different bend 


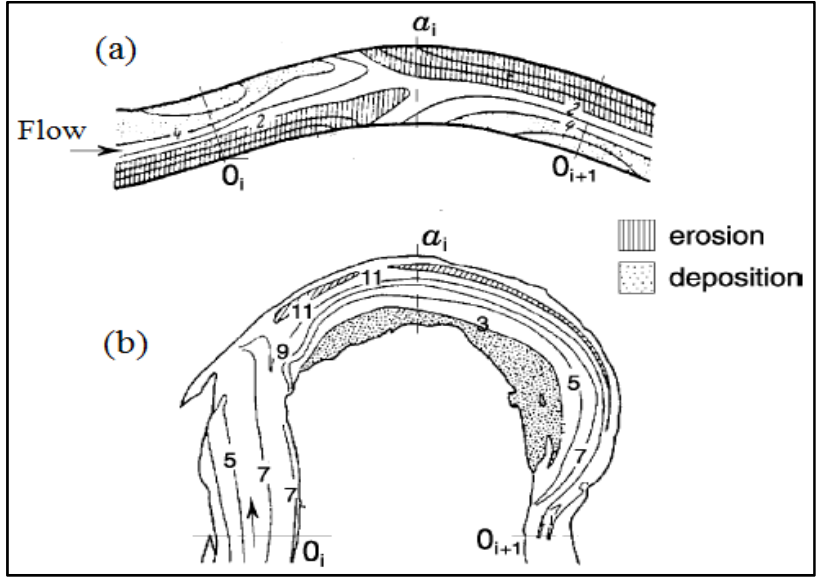

Fig. 1. Bed morphology explaining typical location of pool-point bar zones in streams: a) measurements stated by MAKAVEYEV [1975], b) by Jackson [1975] (cited by DA SILVA and EL-TAHAWY [2008]); source: own elaboration

angles on the location of pool-point bar zones into sinegenerated channel with movable bed and rigid banks.

From modelling the transport of sediments by HECRAS, BERGHOUT and MEDDI [2016] analysed the hydrometric data from two different floods of four stations existing in watershed of Wadi Chemora, Algeria. The analysis consists: sediment transport capacity, volume of sediments delivered to and leaving the system and areas sensitive to erosion and sedimentation. The results showed that out of 96 sections, 50 were eroded and 46 experienced sedimentation. ILINICKI et al. [2010] presents the key principles of new Polish methodology for hydromorphological river surveys which is consistent with the provisions of the water framework directive. The assessment is based on cartographic maps, satellite images and the existing databases. The usefulness of proposed method has been tested on eleven pilot water bodies. The presented approach enables to perform hydromorphological surveys of Polish rivers by 2015, as required under the water framework directive.

In present study, an attempt has been made to develop a predictive formula for pool-point bar position based on the dimensional analysis and multiple nonlinear regressions. The experimental measurements have been conducted along the meander reach which created into the sediment race.

\section{MATERIALS AND METHOD}

\section{EXPERIMENTAL ARRANGEMENT}

The experiments were carried out into a concrete flume $7 \mathrm{~m}$ length, $0.22 \mathrm{~m}$ depth, and $1.5 \mathrm{~m}$ in width and filled to $10 \mathrm{~cm}$ thickness of river sand its properties listed in Table 1. The discharge is supplied by a centrifugal pump

Table 1. The properties of the selected sand

\begin{tabular}{|c|c|c|c|c|}
\hline \multicolumn{3}{|c|}{$\begin{array}{c}\text { Particle size } \\
(\mathrm{mm})\end{array}$} & $\begin{array}{c}\text { Specific gravity } \\
S\end{array}$ & $\begin{array}{c}\text { Geometric standard } \\
\text { deviation, } \sigma g\end{array}$ \\
\hline$d_{16}$ & $d_{50}$ & $d_{84}$ & \multirow{2}{*}{2.68} & 3.83 \\
\hline 0.17 & 0.3 & 1.15 & & \\
\hline
\end{tabular}

Source: own elaboration. and determined by a calibrated flow meter. The discharge is controlled manually by valve.

Figure 2 shows the plan of the carved initial straight channel along the center of the flume with the initial bend at the upstream. The initial bend is a short entrance channel used to establish a disturbance to develop patterns of meander. This initial bend was formed at an angle of $\left(30-40^{\circ}\right)$ to the longitudinal axis of the flume as recommended by a lot of researchers (e.g., FRIEDKIN [1945], SCHUMM et. al. [1987] and YILMAZ [2011]).

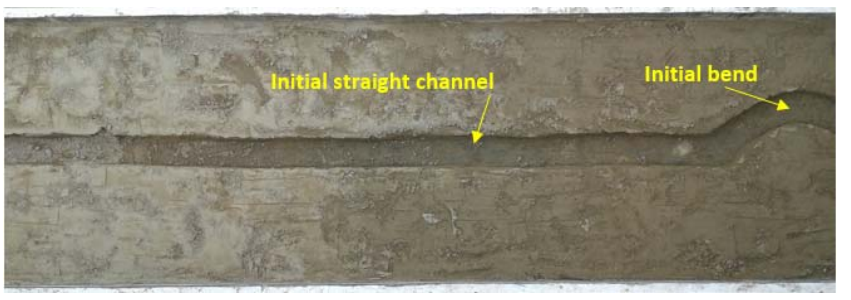

Fig. 2. Initial straight channel with an initial bend prepared for experiment; source: own elaboration

The current experimental program is selected to satisfy the hydraulic conditions that consistent with the context of the flow usual in the rivers, which is turbulent and subcritical flow. The proposed formula by VAN RIJN [1993] was used to find the critical depth average velocity $\left(\bar{u}_{c r}\right)$, for the mean particle size. Based on this formula, the value of $\left(\bar{u}_{c r}\right)$ was $0.175 \mathrm{~m} \cdot \mathrm{s}^{-1}$. Thus for each experimental run the average velocity of flow is compared with the critical depth average velocity for the mean particle size to achieve the required flow conditions and ensure that the sediments can be initiated to transport with flow and to erode the banks.

\section{EXPERIMENTAL METHOD}

The straight channel is firstly carved along the centerline with the initial bend at the upstream. In each run the bed of the initial channel is carefully graded to the desired slope. After the run being started and during the time intervals, the bed and the banks are progressively changed until achieving the state of equilibrium. The equilibrium is considered to occurs when the amount of changes in the channel cross section, meandering path and its migration become negligible and the longitudinal profile of the water surface being approximately constant. BINNS [2006] demonstrated that the effect of stopping and restarting the experimental runs on the estimates of the duration of bed morphology development is judged to be small.

At each time interval, the measurements were done by direct measurements which including water level and cross sections along the channel by using a point gauge. However, the indirect measurements including the pool-point bar location, and geometric characteristics by using timesequence vertical pictures which later converted to data with aid of AutoCAD software and specified coordinate system extension.

Degree of uniformity of the particle size distribution was defined by the value of its geometric standard deviation $\sigma g$, which was represented by $\sigma g=\left(d_{84} / d_{16}\right)^{0.5}$. The 
Table 2. Geometric and hydraulic parameters in the experiment runs

\begin{tabular}{|c|c|c|c|c|c|c|}
\hline $\begin{array}{l}\text { Experiment } \\
\text { run }\end{array}$ & $\begin{array}{l}\text { Initial channel cross section, } \\
\text { width }(\mathrm{cm}) \times \text { depth }(\mathrm{cm})\end{array}$ & $\begin{array}{c}\text { Area of transverse } \\
\text { section }\left(\mathrm{cm}^{2}\right)\end{array}$ & $\begin{array}{l}\text { Flow rate } \\
\left(\mathrm{dm}^{3} \cdot \mathrm{s}^{-1}\right)\end{array}$ & $\begin{array}{c}\text { Initial bed } \\
\text { slope }\end{array}$ & $\begin{array}{l}\text { Width/bank } \\
\text { depth ratio }\end{array}$ & Notes \\
\hline \multicolumn{7}{|c|}{ The experiments series A for initial rectangular section } \\
\hline A-1 & $14 \times 6$ & 84 & 1.33 & 0.005 & 2.33 & \multirow{4}{*}{ initial incised rectangular channel } \\
\hline A-2 & $18 \times 9$ & 162 & 3.00 & 0.005 & 2.00 & \\
\hline A-3 & $14 \times 6$ & 84 & 1.33 & 0.010 & 2.33 & \\
\hline A-4 & $18 \times 9$ & 162 & 3.00 & 0.010 & 2.00 & \\
\hline A-5 & $24 \times 4$ & 96 & 1.33 & 0.005 & 6.00 & \multirow{2}{*}{ initial wide rectangular channel } \\
\hline A-6 & $32 \times 4$ & 128 & 3.00 & 0.005 & 8.00 & \\
\hline \multicolumn{7}{|c|}{ The experiments series B for initial trapezoidal section (side slope angle $45^{\circ}$ ) } \\
\hline B-9 & $14 \times 6$ & 120 & 1.33 & 0.005 & 4.33 & \multirow{2}{*}{ initial incised trapezoidal channel } \\
\hline B-10 & $16 \times 7$ & 161 & 3.00 & 0.005 & 4.28 & \\
\hline B-13 & $18 \times 5$ & 115 & 1.33 & 0.005 & 5.60 & \multirow{2}{*}{ initial wide trapezoidal channel } \\
\hline B-14 & $26 \times 5$ & 155 & 3.00 & 0.005 & 7.20 & \\
\hline
\end{tabular}

Source: own elaboration.

value of $\sigma g>1.3$ can be considered as an indicator for nonuniform sediment as stated by MAATOOQ [1999] and MELVILLE [1984]. The properties of the selected sand are summarized in Table 1.

Numerous experiments with different geometric and hydraulic conditions have been undertaken in this study on different initial incised and wide channel for both rectangular and trapezoidal sections, two flow rates, two initial sand slopes were combined to make various experimental conditions. Table 2 summarizes the characteristics which implemented through the experiments.

The aspect ratio (width/bank depth) is the indication of channel type. As stated by AUEL et al. [2013] and NEZU and RODI [1985] when this ratio is less than 5 the channel is considered as incised, otherwise, the channel is wide. Within the meander reach, the pool-point bar zone has been developed at which the point bar is a deposition along the inner bank of the meander and the pool is the erosion at the outer bank. All experimental runs were conducted starting from a flat movable bed at $t=0$, the bed subsequently being allowed to deform until the equilibrium state was achieved. Figure 3 illustrates the formation of pool-point bar unit through meander evolution for experiment A-4 at $t=480 \mathrm{~min}$.

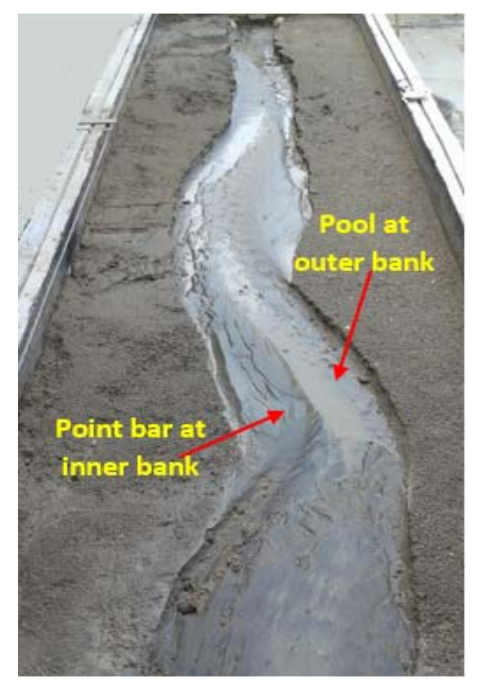

Fig. 3. Formation of pool-point bar unit for experiment run A-4 at $t=480 \mathrm{~min}$; source: own elaboration
Pool-point bar zone developed in a specified meander bend where point bar (deposition) occurs at the inner bank of the meander and pool (erosion) at the outer bank. Figure 4 shows the pool-point bar zone as an example for one of experimental runs undertaken.

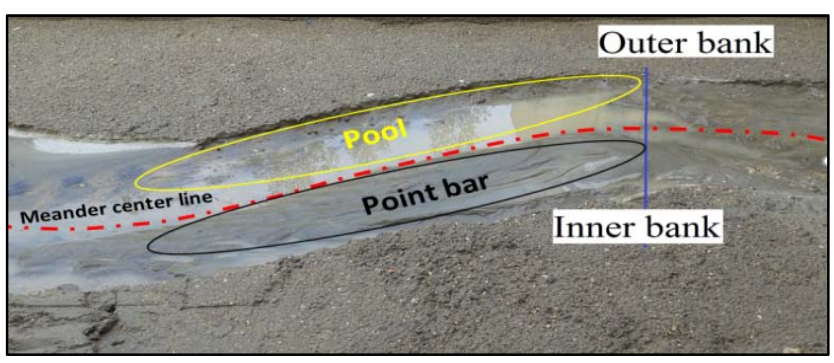

Fig. 4. The pool (erosion) and point bar (deposition) zone; source: own elaboration

With the aim of define the location of erosion-deposition zone, it could be considering the meander between two successive crossing $\left(\mathrm{C}_{i}\right.$ and $\left.\mathrm{C}_{i+1}\right)$. The $L_{c}$ is the distance along the meander center line from the crossing (riffle) to the center of the specified pool-point bar zone in the meander $\left(L_{c}=0\right.$ at the crossover $\left.C_{i}\right)$. This distance can be expressed by the dimensionless parameter $L_{c}: L_{m}$, where $L_{m}$ is the meander length between two successive crossings. Therefore, each different distribution of the pool-point bar zones in meander planform is associated with its specific value of $L_{c}: L_{m}$. Figure 5 is a schematic representation of this assumption.

Based on the review on the main relevant planform geometric characteristics that effect the location parameter $L_{c}: L_{m}$, are, the angle of meander bend $\Phi$, the meander length $L_{m}$, and the top width of channel $(W)$. The measurements have been conducted for the geometric characteristics during the time till achieving the stage of equilibrium. The tool used for measurements is digital camera of 16 Megapixel resolution mounted to fixed frame of height $5 \mathrm{~m}$ above the center point of the experimental flume, to take vertical pictures to observe the geometric characteristics through the stages of meander development. AutoCAD software has been adopted for processing the pictures to calculate the geometric characteristics of the developed meander. The point gauge was used to measure water level. 

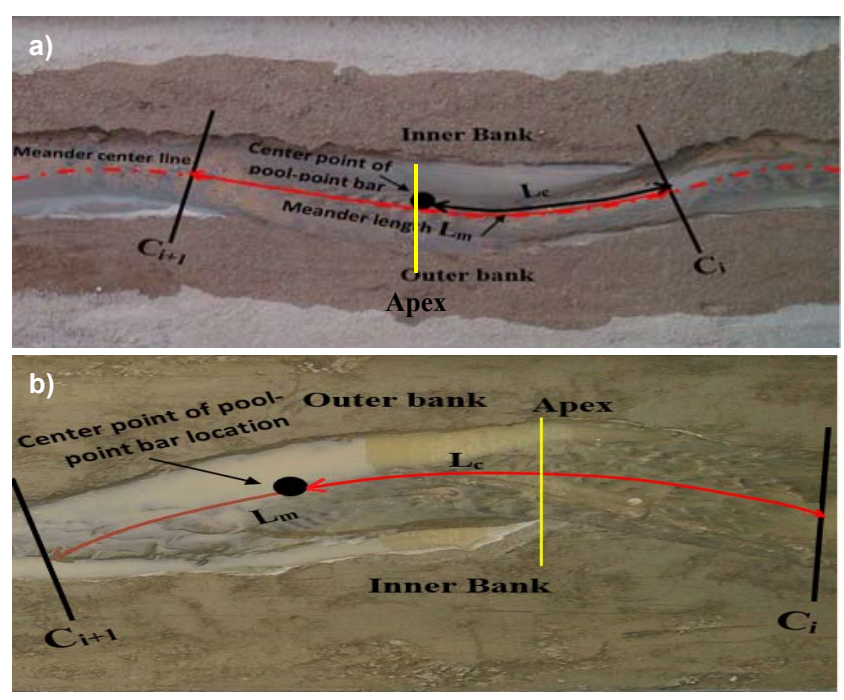

Fig. 5. The location of pool-point bar: a) around the pex for experimental run A-1 at $t=60 \mathrm{~min}, \mathrm{~b}$ ) beyond the apex for experiment runs A-2 at $t=120 \mathrm{~min}$; source: own elaboration

In the present work, different initial incised and wide channel for both rectangular and trapezoidal sections have been adopted, and two initial slopes have been chosen which are $(0.005$ and 0.01$)$ to be within the range of slopes which produces the meandering pattern as approved from pioneer's researchers. The average top width $W$ has been adopted. The hydraulic conditions subject to the current experimental work were selected to satisfy the hydraulic conditions to be consistent with the context of the flow usual in the rivers where, subcritical flow $(\mathrm{Fr}<1)$ and turbulent $(\operatorname{Re}>10000)$.

\section{DIMENSIONAL ANALYSIS}

Several hydraulic and geometric factors affect the pool-point bar location $\left(L_{c}\right)$. According to the review on the relevant parameters and physical considerations, the main independent parameters which affecting and governing the pool-point bar location are categorized and summarized in Table 3.

The dimension analysis was performed using Buckingham $\pi$-theorem. The first stage in the application of Buckingham method was to list the relevant parameters

Table 3. Independent parameters used in dimensional analysis

\begin{tabular}{|l|c|}
\hline \multicolumn{1}{|c|}{ Parameter } & Property of \\
\hline Shear velocity, $u^{*}=(g h S)^{0.5}$ & flow \\
\hline$d_{50}$ & sediment \\
\cline { 1 - 1 } Density of water, $\rho_{w}$ & fluid \\
\cline { 1 - 1 } Viscosity of water $\mu_{w}$ & flow \\
\cline { 1 - 1 } Depth averaged flow velocity $u$ & \multirow{2}{*}{ geometry } \\
\cline { 1 - 1 } Depth of flow $h$ & \\
\hline Top width of meander channel $W$ & \\
\hline Angle of meander bend $\Phi$ & \\
\hline Length of meander bend $L_{m}$ & \\
\hline
\end{tabular}

Explanations: $g=$ gravitational acceleration, $h=$ water depth, $S=$ channel slope.

Source: own elaboration. and to form a matrix with their primary dimensions. The pool-point bar location $L_{c}: L_{m}$ was used as the dependent variable, and specified by the set of nine independent characteristic parameters (Tab. 3). The parameters affecting the pool-point bar location $L_{c}: L_{m}$ could be written in the form:

$$
L_{c}: L_{m}=\mathrm{f}_{\mathrm{o}}\left(d_{50}, \Phi, W, L_{m}, u^{*}, u, \mu_{w}, \rho_{w}, h\right)
$$

Where: $d_{50}=$ median particle size, $\Phi=$ angle bend, $W=$ top width of channel, $L_{m}=$ length of meander bend, $u^{*}=$ shear velocity, $u=$ depth averaged flow velocity, $\mu_{w}=$ viscosity of water, $\rho_{w}=$ density of water, $h=$ depth of water.

The number of primary dimensions involved $(\mathrm{M}, \mathrm{L}$, T), $m=3$ and the number of variable, $n=10$. Consequently, the numbers of dimensionless $\pi$-terms are $10-3=7$, thus:

$$
f_{1}\left(\pi_{1}, \pi_{2}, \pi_{3}, \pi_{4}, \pi_{5}, \pi_{6}, \pi_{7}\right)=\text { constant }
$$

Based on the $\pi$-theorem and after elimination and delimitation process, the following form of the dimensionless functional relationship has been restated:

$$
\frac{L_{c}}{L_{m}}=f_{1}\left(\frac{W}{h} \frac{L_{m}}{w} \frac{h}{d_{50}} \frac{u}{u^{*}} \mathrm{R}_{\mathrm{e}} \Phi\right)
$$

Since the Reynolds numbers for all runs undertaken were larger than 10,000, the fluid viscosity becomes ineffective. On the other hand, it could use the square power with the dimensionless parameter $\frac{u}{u^{*}}$ in order to representing the dimensionless resistance parameter; $C_{f}=\left(\frac{u}{u^{*}}\right)^{2}=$ $\frac{g n^{2}}{h^{1 / 3}}$ which is defining the resistance to the flow in open channel hydraulics. Since the $L_{m}$ appears in the dependent parameter and the effect of the channel width $w$ appears in the term $(W: h)$, it can delete the term $\left(L_{m}: W\right)$ from the functional relationship without affecting the power of correlation of dimensionless function. Consequently, Eq. (2) is rearranged to:

$$
\frac{L_{C}}{L_{m}}=f_{2}\left[\frac{W}{h} \frac{h}{d_{50}}\left(\frac{u^{* 2}}{u^{2}}\right) \Phi\right]
$$

The relationship of Eq. (3) could be derived empirically through the measuring data of the experimental program.

\section{ANALYSIS THE IMPACT OF EACH INDEPENDENT PARAMETER}

The dependent variable $L_{c}: L_{m}$ has been plotted against each of the independent parameter in order to test its impact individually, as shown in Figure 6. Through the evolution of meander, the formation of the morphological aspects would increase the resistance to the flow. Figure 6a and b evidently indicates that the $L_{c}$ is in positive correlation with the width of the meander channel, $W$ and resistance coefficient, $C_{f}$, respectively. While it inversely correlated with the depth of flow, $h$ and the angle of bend $\Phi$, where the last two parameters would reducing the location distance of pool-point bar $L_{\mathrm{c}}$, Figure $6 \mathrm{c}$ and $\mathrm{d}$ respectively. 

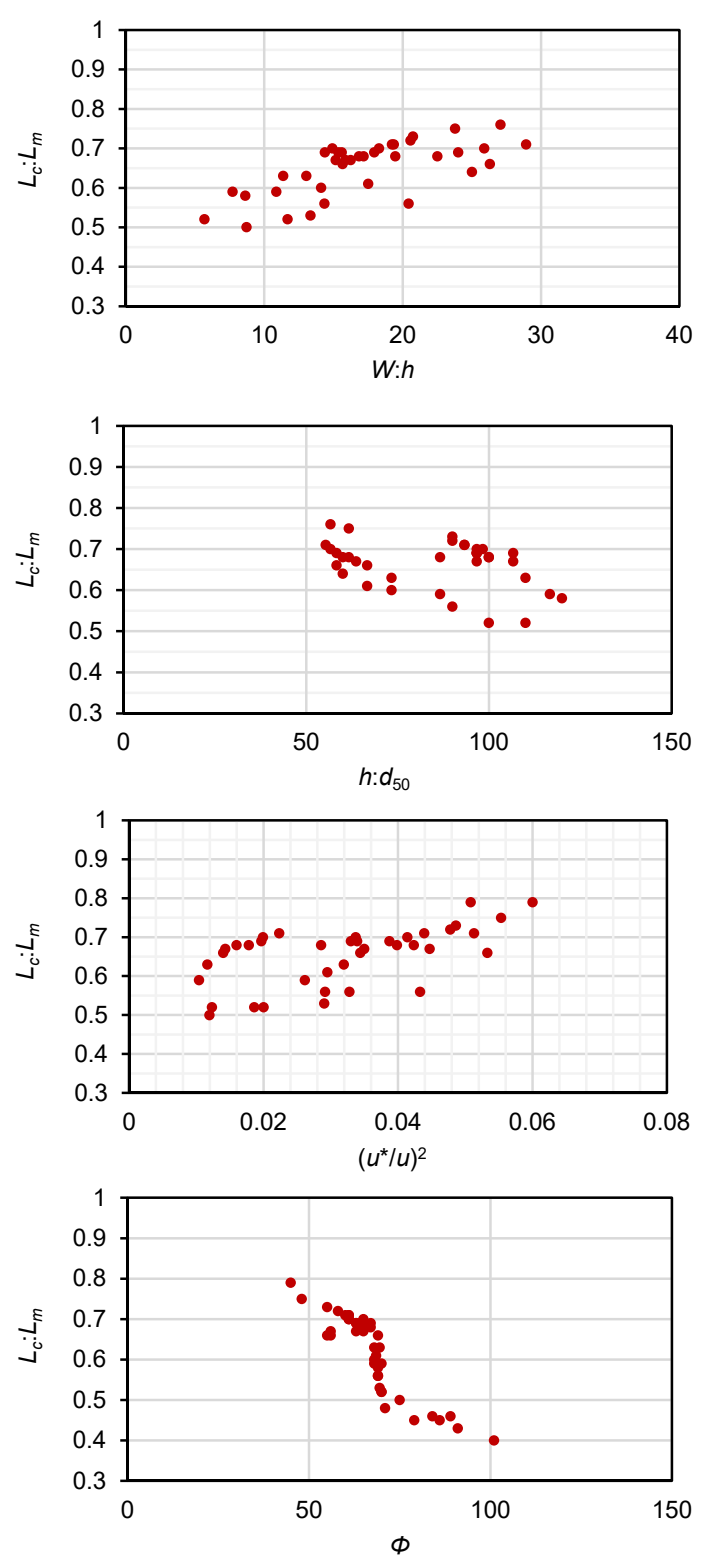

Fig. 6. Relationship of $L_{c}: L_{m}$ with each independent parameters; $L_{c}=$ the distance along the meander center line from the crossing (riffle) to the center of the specified pool-point bar zone in the meander, $L_{m}=$ the meander length between two successive crossings; source: own study

\section{RESULTS}

\section{FUNCTIONAL RELATIONSHIP}

Results are valid only if you have specified functional form that accurately defines the relationship between dependent and independent variables. Furthermore, selecting of good starting values for coefficient and exponents in the proposed relationship is very important, if you use poor starting values, your proposed relationship may fail to converge till when specified the correct functional form of the model. In the present study, numerous functional have been tried, the correlations showing low $R^{2}$ were removed and the starting values for coefficient and exponents have been identified based on iterative procedure (a starting value of 1 was more convenient in the present study), the final form of the functional form can be expressed as:

$$
\frac{L_{c}}{L_{m}}=a\left(\frac{W}{h}\right)^{b}\left(\frac{L_{m}}{w}\right)^{c}\left(\frac{h}{d_{50}}\right)^{d}\left(\frac{u^{* 2}}{u^{2}}\right)^{e}(\Phi)^{f}
$$

Therefore, there are five undetermined exponents and one coefficient. The multiple regression analysis was performed using the SPSS software V.24.

The final and more reliable form of the proposed empirical formula is expressed as:

$$
\frac{L_{c}}{L_{m}}=0.980\left(\frac{W}{h}\right)^{0.1326}\left(\frac{h}{d_{50}}\right)^{-0.059} C_{f}^{0.0827}(\Phi)^{-0.07419}
$$

The predicted pool-point bar location parameter $L_{c}: L_{m}$ was compared with the measured ones as shown in Figure 7. The figure indicated that the developed formula showed good agreement between the predicted and measured values with a coefficient of determination $R^{2}=0.93$.

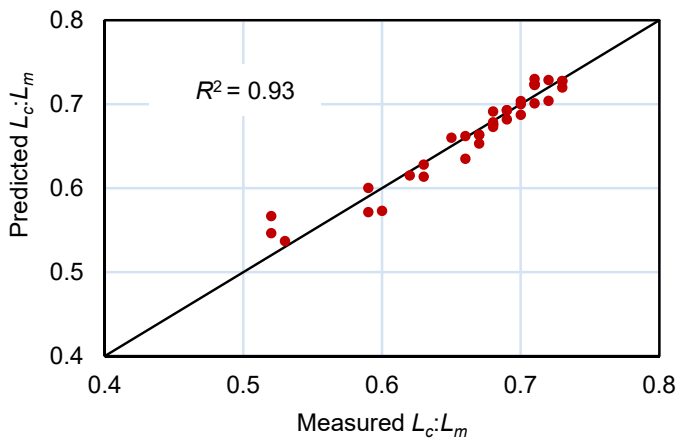

Fig. 7. Predicted and measured data of pool-point bar location parameter $L_{c}: L_{m} ; L_{c}, L_{m}$ as in Fig. 6; source: own study

Table 4 presents the list of measured and predicted $L_{c}: L_{m}$ between $15 \mathrm{~min}$ until equilibrium state have been achieved for runs A-1, A-4, and B-14 respectively as illustrative examples.

\section{VERIFICATION OF THE DEVELOPED FORMULA}

The developed empirical formula has been evaluated with another set of experimental data to verify its reliability for application at various practical conditions. The predicted and measured data of pool-point bar location are compared as shown in Figure 8. It obviously indicates that the results which obtained from the presented formula having good agreement with the measured values. The indication of this agreement is the $R^{2}=0.88$ as well as observing well spreading of the data points around the perfect line. This implies that the introducing of this formula could be a practical solution for identifying the location of the relevant morphological aspect.

\section{STATISTICAL ANALYSIS}

With the aim of evaluating the performance of the introduced formula in estimating the pool-point bar location with the measured results, three statistical indicators, bias, Nash-Sutcliffe efficiency (NSE), and mean absolute error $(M A E)$, were used. 
Table 4. Measured and predicted of the pool-point bar location $L_{c}: L_{m}$ for three runs

\begin{tabular}{|c|c|c|c|c|c|c|}
\hline $\begin{array}{c}\text { Time } \\
(\mathrm{min})\end{array}$ & $w: h$ & $h: d_{50}$ & $\left(u^{*}: u\right)^{2}$ & $\begin{array}{c}\Phi \\
(\text { deg. })\end{array}$ & $\begin{array}{c}L_{c}: L_{m} \\
\text { measured }\end{array}$ & $\begin{array}{c}L_{c}: L_{m} \\
\text { predicted }\end{array}$ \\
\hline \multicolumn{7}{|c|}{ Run A-1 } \\
\hline 15 & 5.67 & 100.0 & 0.012 & 70 & 0.52 & 0.546 \\
\hline 30 & 7.69 & 86.7 & 0.010 & 70 & 0.59 & 0.559 \\
\hline 45 & 11.36 & 73.3 & 0.012 & 69.5 & 0.63 & 0.599 \\
\hline 60 & 15.65 & 66.7 & 0.014 & 69 & 0.66 & 0.640 \\
\hline 120 & 16.23 & 63.7 & 0.014 & 65 & 0.67 & 0.648 \\
\hline 180 & 19.46 & 61.7 & 0.016 & 65 & 0.68 & 0.661 \\
\hline 240 & 22.50 & 60.0 & 0.018 & 64 & 0.68 & 0.676 \\
\hline 300 & 24.00 & 58.3 & 0.020 & 63 & 0.69 & 0.686 \\
\hline \multicolumn{7}{|c|}{ Run A-4 } \\
\hline 15 & 8.61 & 120.00 & 0.0186 & 69 & 0.52 & 0.549 \\
\hline 30 & 10.86 & 116.66 & 0.0261 & 68 & 0.59 & 0.584 \\
\hline 45 & 13.03 & 110.00 & 0.0320 & 68 & 0.63 & 0.614 \\
\hline 60 & 14.38 & 106.66 & 0.0344 & 67 & 0.66 & 0.624 \\
\hline 120 & 15.16 & 106.66 & 0.0447 & 56 & 0.67 & 0.652 \\
\hline 180 & 16.83 & 100.00 & 0.0399 & 65 & 0.68 & 0.659 \\
\hline 240 & 17.17 & 100.00 & 0.0424 & 64 & 0.68 & 0.665 \\
\hline 300 & 17.93 & 96.66 & 0.0387 & 63 & 0.69 & 0.665 \\
\hline 360 & 18.28 & 96.66 & 0.0414 & 61 & 0.70 & 0.672 \\
\hline 420 & 19.21 & 93.33 & 0.0439 & 61 & 0.71 & 0.687 \\
\hline 480 & 19.36 & 93.33 & 0.0513 & 60 & 0.71 & 0.710 \\
\hline 540 & 20.56 & 90.00 & 0.0478 & 58 & 0.72 & 0.712 \\
\hline 600 & 20.74 & 90.00 & 0.0486 & 55 & 0.73 & 0.713 \\
\hline \multicolumn{7}{|c|}{ Run B-14 } \\
\hline 15 & 8.71 & 103.33 & 0.0120 & 71 & 0.50 & 0.553 \\
\hline 30 & 11.67 & 100.00 & 0.0200 & 70 & 0.52 & 0.602 \\
\hline 45 & 13.33 & 100.00 & 0.0291 & 69.5 & 0.53 & 0.635 \\
\hline 60 & 14.33 & 100.00 & 0.0328 & 69 & 0.56 & 0.645 \\
\hline 120 & 14.92 & 98.33 & 0.0337 & 65 & 0.70 & 0.653 \\
\hline 180 & 15.34 & 96.66 & 0.0330 & 65 & 0.69 & 0.656 \\
\hline 240 & 15.59 & 96.66 & 0.0339 & 64 & 0.69 & 0.658 \\
\hline 280 & 15.86 & 96.66 & 0.0350 & 63 & 0.67 & 0.661 \\
\hline
\end{tabular}

Explanations: $L_{c}=$ the distance along the meander center line from the crossing (riffle) to the center of the specified pool-point bar zone in the meander, $L_{m}=$ the meander length between two successive crossings, other parameters as in Tab. 3 .

Source: own study.

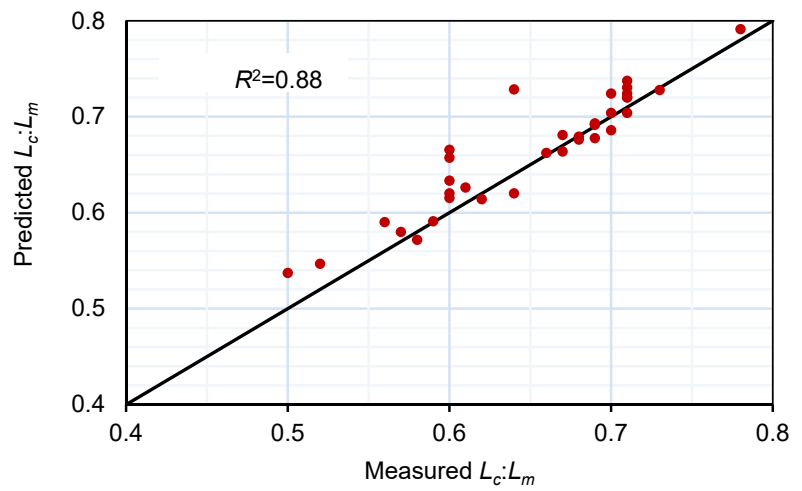

Fig. 8. Predicted and measured data of pool - point bar location parameter $L_{c}: L_{m}$ for verification process; $L_{c}, L_{m}$ as in Fig. 6; source: own study

$$
\begin{aligned}
& \text { bias }=\frac{1}{N} \sum_{i=1}^{N}\left(X_{\text {pred }}-X_{\text {exp }}\right) \\
& N S E=1-\left[\frac{\sum_{i=1}^{N}\left(X_{\text {exp }}-X_{\text {pred }}\right)^{2}}{\sum_{i=1}^{N}\left(X_{\text {exp }}-\bar{X}_{\text {exp }}\right)^{2}}\right]
\end{aligned}
$$

$$
M A E=\frac{1}{N} \sum_{i=1}^{N}\left|X_{\text {pred }}-X_{\text {exp }}\right|
$$

Where $N$ is the total measurements.

Bias measures the tendency of the predicted values to be larger or smaller than their observed ones; the optimal value is 0 , positive values indicate a tendency to overestimation, and negative values indicate a tendency to underestimation. $M A E$ values of 0 indicate an optimal fit. NASH and SUTCLIFFE [1970] proposed Nash-Sutcliffe efficiency, $N S E$ which is a normalized statistic that determines the relative value of the residual variance compared to the measured data variance. NSE indicates how well the plot of measured versus predicted values fits the 1:1 line (line of perfect agreement). NSE equal to 1 being the optimum value. Values between 0 and 1 are generally indicated as acceptable levels of performance, whereas values less than 0 indicates that the mean observed value is a better predictor than the simulated value, which indicates unacceptable performance. This indicator is recommended by ASCE, 1993.

The statistical evaluation for both prediction and verification results as well as the boundary conditions of application is listed in Table 5.

Table 5. Statistical evaluation of the proposed formula of poolpoint bar location

\begin{tabular}{|l|c|c|c|c|}
\hline \multicolumn{1}{|c|}{ Case } & Bias & MAE & $N S E$ & $R^{2}$ \\
\hline Prediction of formula & 0.0004 & 0.011 & 0.935 & 0.93 \\
\hline Verification of formula & 0.013 & 0.018 & 0.826 & 0.88 \\
\hline
\end{tabular}

Explanations: $N S E=$ Nash-Sutcliffe efficiency, $M A E=$ mean absolute error, $R^{2}=$ determination coefficient.

Source: own study.

The low values of the bias and $M A E$ along with the high values of NSE and $R^{2}$ are good indication to the reliability of the formula. However, the positive sign of bias refers to the overprediction tendency. This tendency to any predictive equation is preferred in practice because the resulting data being into the safe side.

\section{CONCLUSIONS}

A new nonlinear multiple regression formula was established to predict pool-point bar location. The predicted results show that the developed formula gave good correlation $\left(R^{2}=0.93\right)$ for pool-point bar location. It is indicated from the present experiment measurements involving a variation in the dependent variable $L_{c}: L_{m}$ against each of the independent parameter that the relevant parameters play a significant role in determining the location of poolpoint bar location. The results obtained from present analysis showed that there is a trend for the location of the erosion-deposition zones to shift further downstream the apex for larger values of aspect ratio $W: h$ and the friction factor $\left(u^{*} / u\right)^{2}$ and move to upstream for larger values of ratio $h: d_{50}$ and bend angle $\Phi$. The proposed formula must be regarded as strictly valid for the range of $30 \geq w / h \geq 5$, $101^{\circ} \geq \Phi \geq 44^{\circ}, 120 \geq h / d_{50} \geq 55$, and $0.06 \geq\left(u^{*} / u\right)^{2} \geq$ 0.01 . The presented methodology should assist practical hydraulic engineers to locate new hydraulic structures. 
Furthermore, this methodology could be applied to river restoration works (river training) for determining the need for and design countermeasures structures against the effects of morphological features.

\section{REFERENCES}

ASCE 1993. Criteria for evaluation of watershed models. Journal of Irrigation and Drainage Engineering. Vol. 119. Iss. 3 p. 429-442.

Auel C., AlbayraK I.C., Boes R.M. 2013. Turbulence characteristics in supercritical open channel flows: Effects of Froude number and aspect ratio. Journal of Hydraulic Engineering. Vol. 140. Iss. 4 p. 1-30. DOI 10.1061/(asce)hy.1943-7900. 0000841 .

Berghout A., Meddi M. 2016. Sediment transport modelling in Wadi Chemora during flood flow events. Journal of Water and Land Development. No. 31 p. 23-31. DOI 10.1515/ jwld2016-0033.

BINNS A.D. 2006. Time-evolution and stability of the bed in sinegenerated meandering streams: An experimental study. M.Sc. Thesis. Kingston, Canada. Queen's University.

Da Silva A.M.F., El-Tahawy T. 2008. On the location in flow plan of erosion-deposition zones in sine-generated meandering streams. Journal of Hydraulic Research. Vol. 46(S1) p. 49-60. DOI 10.1080/00221686.2008.9521939.

FRIEDKIN J.F. 1945. A laboratory study of the meandering of alluvial rivers. Vicksburg, Mississippi. US Army Engineer Waterways Experiment Station pp. 40.

ILNicki P., GóRecki K, GrZybowski M, KrZemińska A., LeWANDOWSKI P., SOJKA M. 2010. Principles of hydromorphological surveys of Polish rivers. Journal of Water and Land
Development. No. 14 p. 3-13. DOI 10.2478/v10025-0110001-9.

MAATOOQ J.S. 1999. Evaluation, analysis and new concepts of scour process around bridge piers. PhD Thesis. Baghdad. University of Technology. Building and Construction Eng. Dept. pp. 171.

Melville B.W. 1984. Live bed scour of Bridge Piers. Journal of Hydraulic Engineering, ASCE. Vol. 110. No. 9 p. 1234 1247.

NASH J.E., Sutcliffe J.V. 1970. River flow forecasting through conceptual models. P. I. A discussion of principles. Journal of Hydrology. Vol. 27. Iss. 3 p. 282-290.

NezU I., RODI W. 1985. Experimental study on secondary currents in open channel flow. Proc. 21st IAHR Congress. Melbourne, Australia p. 114-120.

SChumm S.A., Mosley M., WeAver W. 1987. Experimental fluvial geomorphology. New York. Wiley. ISBN 9780471830771 pp. 413.

VAN RIJN L.C. 1993. Principles of sediment transport in rivers, estuaries and coastal seas. Blokzijl, The Netherlands. Aqua Publications. ISBN 9080035629 pp. 790.

Whiting P.J., Dietrich W.E. 1993. Experimental constraints on bar migration through bends: Implications for meander wavelength selection. Water Resources Research. Vol. 29(4) p. 1091-1102.

YaLIN M.S., DA SiLVA A.M.F. 2001. Fluvial processes. IAHR Monograph. Delft, the Netherlands. IAHR. Vol. 1. ISBN 9080564923 pp. 197.

YILMAZ L. 2011. Modeling of developed meanders of an alluvial channel. In: Sediment transport. Ed. S.S. Ginsberg. London. Pergamon Press Inc. p. 215-236.

\section{Jaafar S. MAATOOQ, Luay HAMEED}

\section{Określanie lokalizacji odsypiska na podstawie badań eksperymentalnych}

\section{STRESZCZENIE}

Morfologiczne zależności rozwoju meandrów, określane cechami hydraulicznymi i geometrycznymi, są ważne dla gospodarki wodnej. W przedstawionej pracy opisano eksperymentalne badania rozwoju meandrów celem uzyskania prognostycznego wzoru do określenia lokalizacji odsypiska z użyciem techniki analizy wymiarowej i wielorakiej regresji nieliniowej. Przeprowadzono serię eksperymentów nad przemieszczaniem niejednorodnego piasku rzecznego poprzez łączenie różnych parametrów hydraulicznych i geometrycznych, aby osiągnąć różne warunki doświadczalne, które mają wpływ na lokalizację odsypiska. Na podstawie obserwacji i pomiarów z doświadczeń zmienność lokalizacji można interpretować jako zmienność w czasie hydraulicznych i morfologicznych cech tworzenia meandru, które odpowiednio zmieniają położenie odsypiska. Uzyskany wzór weryfikowano, używając innego zestawu danych eksperymentalnych i testowano za pomocą trzech wskaźników statystycznych. Wyniki wskazują, że proponowany wzór ma dużą wiarygodność w praktycznym szacowaniu lokalizacji odsypiska. Wiarygodność tę sprawdzono za pomocą wskaźników statystycznych, w których uzyskano mniejsze wartości dla błędu systematycznego - 0,0004 i średniego błędu bezwzględnego (MAE) - 0,011, podczas gdy wyższe wartości osiągnięto dla współczynnika efektywności Nasha-Sutcliffe’a (NSE) - 0,935 i współczynnika determinacji $R^{2}-0,930$.

Słowa kluczowe: badania doświadczalne, cechy morfologiczne, ewolucja meandru, odsypisko, piasek rzeczny 